\title{
PARADIGM SHIFT IN REGIONAL AND URBAN DEVELOPMENT STUDIES IN THE AGE OF GLOBALIZATION: THE CASE OF DEVELOPING THE SOUTH OF EGYPT
}

\author{
Ahmed O. El-Kholei, Ph.D. \\ Associate Professor, Department of Architecture, \\ Faculty of Engineering, Minufiya University, EGYPT
}

\begin{abstract}
Development management of human settlements in developing countries has gained planners' attention. Regional imbalances associate with urban problems including environmental degradation, housing problems, unemployment and the like. Different development approaches have experienced limited effectiveness. The philosophical foundation of these approaches and the decision-making process are among the reasons for the limited success. Today in the age of globalization, a new mode of capital accumulation associates with new modalities of thinking. This paper presents the design of the project to articulate a Strategic Plan for the Development of Human Settlements, South of Egypt, using post-modernist planning mode of thinking and a participatory decision-making process. Postmodern planning emphasizes a combination of instrumental and communicative action directed by emancipatory interests where planning is an enlightening social process. It offers a framework that is suitable for the dynamic nature of contemporary societal transformations. Postmodern planning offers new definitions for old problems thus presenting new solutions that could be adequate in the coming millenium.
\end{abstract}

Maunscript Received From Dr. Alned El-Khole. on 31/10/1998.

Accepted on : 10/12/1998.

Engineering Researcth Bulletin, Vol. 22, No. 1, 1999.

Minufiya University, Faculty of Engineering, Shebin El-Kom, EGYPT, iss 1110-1180. 


\section{I) INTRODUCTION}

Globalization is a phenomenon attributed by the commonality of communication and information. It results from the movement of capital and labor, as well as information beyond national boundaries, thus transforming the geography of production, the division of labor, and patterns of both production and consumption.

The pace of global economic integration, i.e., widening and intensifying of international linkages in trade and finance has accelerated over the past decade. Some developing countries have been part of this trend of growing integration in aggregate. Global integration matters because it tends to promote higher economic growth brought via channels of better resource allocation, technology transfer and access to foreign finance (World Bank 1996).

Fast integrators in a global economy are developing countries who successfully achieved exceptionally large increases in trade, manufactures exports and foreign direct investment ratios, such as the Asian tigers, i.e., Korea, Singapore, Taiwan, and Hong Kong. The group also includes some commodity exporters, such as Chile, Malaysia and Turkey, suggesting that commodity production does not condemn a country to low productivity and in ability to diversify. Successful exporters encouraged investment by strengthening the private sector, attracting foreign direct investment and developing research and infrastructure-Fast integrators are attributed by high investments in infrastructure (lbid.).

Integrating in a global economy faces eight interrelated challenging issues (Amirahmadi 1990). First, exchange rate could be a comparative advantage to attract global activities. Second, saving-investment gap discourages foreign investors from locating their production plants to certain developing countries. Third, deficit in the balance of payments often has negative impact on inflation rate, saving-investment ratios and exchange rates, thus inhibiting foreign finance from banking development projects. Fourth, inflation resulting from excessive money supply and rapid money velocity which in turn affect exchange rates and trade balance. Fifth, development of skilled human resources to easily transfer technology and know-how thus enhancing production processes. Sixth, the capacities of cities of developing countries in terms of infrastructures, ports, communication networks and the like for foreign capital to use as means of production. Seventh, demandsupply gap reflects the distortion in the economy. It is a manifestation of inequitable distribution of wealth and bias in allocating government expenditures. Eighth, the need for political reforms to (a) set a friendly business environment by privatizing some economic sectors, such as agriculturc, manufacturing and tourism, (b) realistic pricing services delivery and (c) participation in decision-making at the national and local levels.

Not all Egyptian urban settlements are part of the global urban system. The reason is obvious. The urban centers that fulfill the requirements, i.e., provide the global economy with services and produce goods that match the global specifications meeting the global demand are part of the global urban system. Those settlements that do not offer such services or produce these commodities to meet global demand cannot be part of the global urban systems, and therefore, are denied the chance to compete for foreign direct investments. The Egyptian urban system suffers from primacy. Globalization contributes to increasing regional disparities. Locally, some 
Egyptian human settlements, such as Cairo, Luxor and Hurghada, are becoming more and more integrated in the global urban system. Settlements that are integrated in the global urban systems attract influx of rural-urban migration that strains social and physical infrastructures, and creates excess need for job opportunities and shelter.

In parallel, Egypt has successfully implemented a program for Economic Reform and Structural Adjustment (ERSA), which aimed to replace the state-led centrally, administered economy to a free market system. This shift required The Government of Egypt (GOE) to renounce old dogmas and assume a specific role. "The Government is neither a farmer, manufacturer nor trader, but rather an honest organizer that provides the appropriate environment for economic activity..." (Cabinet of Ministers, March 1997). Further the GOE has launched several ambitious national projects that will transfer Egypt into a Newly Industrialized Country (NIC) as the Asian Tigers requiring cautious planning of human settlements (El-Kholei and Abu-Zekry 1993). Donor agencies, meanwhile, are faced with excess demand for funds and assistance, and constrained by limited resources. Simultaneously, the role of non-government organizations in the development process is gaining momentum, and can reach those who Governmental programs and the market cannot reach. Non-Government Organizations (NGOs) represent an opportunity to initiate, stimulate and institutionalize participatory processes to prioritize community's needs and identify means to fulfill them.

This paper consists of four sections. It begins by presenting the various development paradigms and their limitations. Next, the paper presents the strategy of the Government of Egypt in extending development efforts to new frontiers. The paper presents the Strategic Plan for Developing Human Settlements in the New Valley, South of Egypt. Finally the paper presents a conceptual discussion of the project design.

\section{II) DEVELOPMENT APPROACHES}

Thomas Kuhn (1960) in his book "The Structure of Scientific Revolutions", proposed that experts view the universe through certain fundamental laws governing their research methodologies and values. Unaware of these biases, experts use laws and theories that reflect their modus operandi in research to interpret a phenomenon and recommending actions to cope with it. He named this set of values and beliefs by a paradigm that provides its subscriber with a picture of the world both as it is, and as it should be. Policy analyses and planning are forms of dogma since they provide experts, who advise decision-makers, with the kind of intervention to be considered. Paradigms are different, and an over arching paradigm that reconciles the differences does not exist.

Conventional development theories can be grouped under the following four headings:

1. Bureaucratic (top-down) Approach that suits international and national public agencies, such as World Bank, where development is totally organized and directed from the center. An expert's analysis of the problem is the point of departure towards prescribing the development strategy and implementation arrangement once funds are secured to finance the process. According to this paradigm development is a function in (a) capital investment that depends on 
volume, direction and propensities to economic exchange, (b) inputs and (c) linkages.

The limitation of the approach raises from the administrative structure of the organization responsible for development. It is often big with high overhead costs, and of limited effectiveness to end-users. Another problem associated with the size of the implementing agency is becoming insensitive to problems of scale and favors large efficient operations. Usually the implementing agency loses focus when defining development objectives, and ignores local knowledge and expertise in favor of advanced technology and processed information that impact the social system, thus producing projects that the end-users might not appreciate. It is clear that the decision-making process does not make room for end-users to participate and assume responsibility for the produced projects-an issue that threatens the sustainability of the produced projects that could prove to be an environmental burden and/or an economic and financial loss.

2. Commercialization (outside-in) Approach that is based on the laissez-faire doctrine. Development is to modernize traditional industries (whether agriculture, manufacturing... etc.) to stimulate demand. Transforming production processes, engaging in monetized system and opening to outside economy will develop the community and will over weigh temporary social costs that the community will incur in the early stages of development (Friedman 1982).

The approach has all the weaknesses and limitations associated with the laissezfaire doctrine. Evidence show that trickle-down effects of development do not always occur. Market forces do not register negative concerns, accommodate the preference of future generations and over shadow social values. The approach ignores small-scale producers in pursuit of economies of scale and production. The decisions are made outside the community, and only the interests of the business community that matters raising the issue of whether the development is sustainable.

3. Participatory (bottom-up) Approach that takes the community as its frame of reference believing that the locals will not cooperate unless they have a good reason to do so. Experts are not advice-providers but facilitators working with the people. Local knowledge and expertise have to be tapped within the project design. Capital and local resources, such as sweat equity, are mobilized to implement development projects. The approach stresses on creating viable local organizations (Schumacher 1973).

Stressing the need to create viable local organizations to assume the responsibility of development requires organizing costs. This development modality requires creating a funding mechanism to insure sustainability to support projects that the locals identify. The approach is geared to the locality and has little to do with transforming state policies at the macro levels. It is appropriate for the work of NGOs in slum, squatter and rural settlements but might not be used effectively at the urban or regional levels.

4. Mobilization (inside-out) Approach that originated when Marxist scholars investigated problems of modernization. They argued that small producers lose 
when competing with big enterprise in a free market (Wallerstien 1989, Amin 1985, Soja and Tobin [1975] 1979, and Slater [1974] 1979). The modern sector of developed countries allies itself with domestic elite against the interest of small producers. Bureaucrats rationalize controlling the production sectors of the economy, and the small producers, therefore, fail to perceive the true exploitation that they experience since they believe that development is nationally. The revolution starts by working from within the system to change the status quo. Whenever an advisory mode is evident local cells are organized to enlighten the small producers. Mobilization is, then, to raise the awareness of the small producers and build solidarity to defend interests of the proletariat.

A strategy rooted in class-division often alienates local groups who share common interests. Market mechanisms are often idle paving the way to wasteful and inefficient practices. Despite their faults, capitalist systems have proven their durability.

\section{III) CONCEPUTAL DISCUSSION}

The writings in the planning theory concerned with the validity of the rational model and the philosophy of social sciences use in planning have been scrutinized (Lindblom [1959] 1973, Altshuler [1965 1973, Webber 1983, Christensen 1985). Planners have found the limitations of social research techniques in forecasting human behavior. Today in response to these findings, planners will have to shift their interest from "end product" to "process" particularly in a new era of globalization, information-age and new modes of capital accumulation (Abu-Zekry and El-Kholei 1993). Postmodern planning rose in association with cultural transformation accompanied with political, social and economic transformations.

Postmodern planning is a response to the limitations of the modernist rational planning model. It is a revision to specific modernist excesses. It is a radical departure from modern "determinism" and "rationality." It is linked to a later stage of capitalism, i.e., the stage of global market and multinational corporations that led to redefining the role of the State.

[Postmodernism] is deconstructive in the sense of questioning and establishing a skeptical distance from conventional beliefs and more effectively, trying both to ascertain who derives value from upholding their authority and to displace them; antifoundationalist in the sense of dispensing with universals, as bases for truth; nondualistic in the sense of refusing the separation between subjectivity and objectivity along with the array of dualism it engenders including the splits between truth and opinion, fact and value; encouraging of plurality and difference (Milroy 1991: 13).

Postmodern planning constitutes some resistance to authorized conventions. It asserts the importance of context giving rise to paradoxes. The postmodernist reasoning both-and logic replaces modernist thinking based on $i f$-then logic.

Postmodernist analyses draw on nonpositivist interpretations where the expert looks : into: (a) the reflexivity of language (Mandelbaum1991, Milroy 1991); (b) relations between and among things (objects/issues) instead of things themselves (Beauregard 1991); (c) abandoning cause-and-effect reasoning because increased understanding cannot set directions but will only reveal differences (Beauregard 1991); (d) adopt 
the role of a reflective practitioner who contextualizes an object according to the public's perception (Ligget 1991), then develops theory and practice according to that understanding (Shon 1982, 1983) prescribed; and (e) identify plurality and difference.

The development approaches presented earlier experienced limited success because of their philosophical foundation. All four approaches stem from the deterministic rational paradigm. The bureaucratic, commercialization and mobilization approaches begin by identifying the needs rather than knowing what exist in the community. The participatory approach begins from what the community needs, which is often misleading venue to formulate national or regional development policies. Deriving aggregate demand has proven to be more reliable in policy formulation rather than needs analyses that often do not acknowledge assets that the community possesses.

Modernist rational development approaches focus on end product rather than process, and therefore are rigid and unable to cope with dynamic societal transformations brought by globalization. Decisions made at the board of directors of Multi-National Corporations (MNCs) can explain the transformations in the role of central and local governments, the functions and specialization of human settlements in developing countries, transformation in the production capacities and consumption patterns, and spatial transformations of human scttlements.

In an attempt to make up for limited success of the past experiences, the project for developing the South of Egypt ${ }^{1}$ was based on a different thinking mode that is rooted into the postmodernist doctrine with an eye on globalization and its mixed consequences. The next section of the paper presents the project design, followed by a conceptual analysis of the project.

\section{IV) DEVELOPMENT OF THE SOUTH: THE PROJECT}

\section{IV-1) Context:}

The Egyptian urban system suffers from urban primacy associated with congestion in human settlements. Urban primacy has negative impact on the environment and efforts for economic development. Today Egypt is at a level of economic development that requires initiating a process of polarization reversal, i.e.; to attract investments and human resources away from congested human settlements to correct distortions in the urban system. Restructuring the Egyptian urban system, which will limit regional disparities, is a sine quo non to achieve remarkable economic growth rates, insure equitable distribution of economic gains, and regenerate and conserve environmental resources.

\footnotetext{
${ }^{1}$ The Ministry of Housing, Utilities and Urban Communities (MHUUC) and the United Nations Development Programme (UNDP) are the sponsor of this project. The author prepared the project design (objectives, outputs and activities) in collaboration with both parties, then drafted the project document and served as a strategic planning advisor to the Project Management Unit (PMU). This project is a detailed phase of the National Development Land Use Plan (NDLUP) that identified the location of 44 new settlements of which 18 settlements are in the study area.
} 
Longitude 27 -33 East and latitude 22-28 North define the boundaries of the study area. It consists of the Governorates of Assuit, Suhag, Qena, Aswan and the New Valley. The population of the study area exceeds 10 million. Most of the population is concentrated in cities and villages in the Nile Valley. Most employment is in agriculture and service sector. Adult illiteracy is wide spread, particularly among females. In 1996, literate adult females in the study area mount to about 38.5 percent that is below the national average ( 49.4 percent) for the same year. Unemployment is evident, especially among women and youth. In 1995, unemployed females represented about 19.6 percent of the unemployed persons in the study area. In 1995, the unemployed persons youngsters (15-29 years old) represent 13.6 and 7.5 percent of the unemployed in urban and rural arcas, respectively. Also there are environmental threats due, in part, to shortage in wastewater management (collection and treatment), lack of solid waste management schemes, and shortage in providing safe drinking water. The study area lacks social infrastructure, such as schools, clinics, and so forth. The following two tables compiled some information about the services and economic conditions of the area.

Table 1: Selected indicators of the availability of social and physical infrastructures in the study area

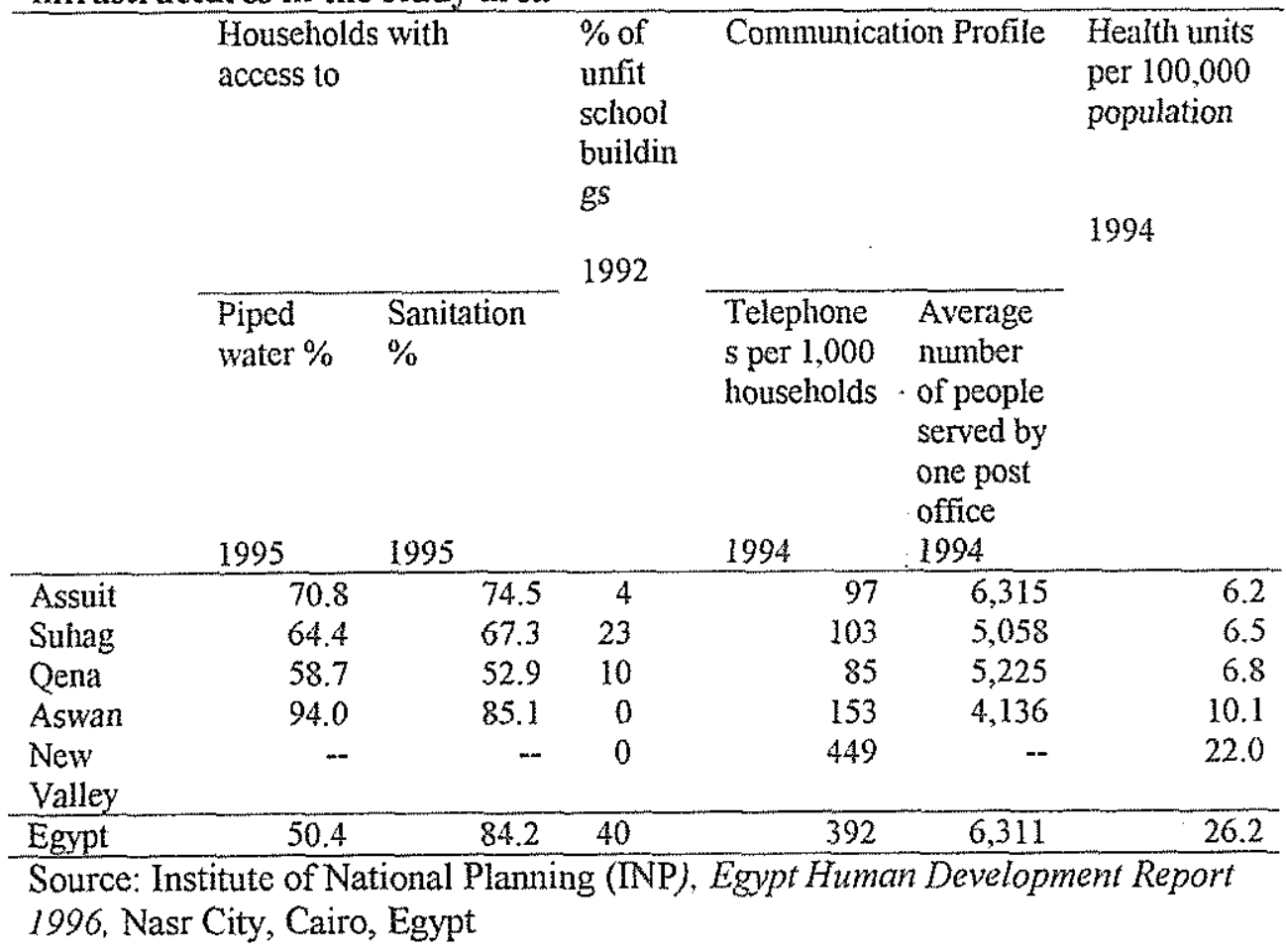


Table 2: Selected indicators of the economic conditions in the study area

\begin{tabular}{|c|c|c|c|c|c|c|}
\hline & \multicolumn{2}{|c|}{$\begin{array}{l}\text { Poor persons }(\% \text { of } \\
\text { total) }\end{array}$} & \multirow{2}{*}{$\begin{array}{l}\text { Unemployment } \\
\text { rate }(\%) \\
\text { Adults } 15-29\end{array}$} & \multicolumn{3}{|c|}{ Percentage of Labor Force $15-64$ in } \\
\hline & Total & $\begin{array}{l}\text { Ultra } \\
\text { poor }\end{array}$ & & Agriculture & Industry & Service \\
\hline & $1995 / 96$ & $1995 / 96$ & 1995 & 1995 & 1995 & 1995 \\
\hline Assuit & 53.4 & 25.8 & 29.8 & 35.2 & 11.8 & 53.0 \\
\hline Suhag & 39.4 & 12.3 & 22.6 & 45.9 & 10.7 & 43.4 \\
\hline Qena & 38.3 & 15.1 & 18.9 & 47.5 & 11.8 & 40.6 \\
\hline Aswan & 30.8 & 10.1 & 61.4 & 18.2 & 6.4 & 75.4 \\
\hline New Valley & - & - & 57.6 & 3.6 & 4.4 & 92.0 \\
\hline Egypt & 22.9 & $\overline{7.4}$ & 29.2 & 29.6 & 18.5 & 51.9 \\
\hline
\end{tabular}

Source: Institute of National Planning (INP), Egypt Human Development Report

1996. Nast City, Cairo, Egypt

\section{IV-2) The Strategy of GOE:}

...[M]an...is regarded as the pivot of the development process including his food, health, education, recreation and environment. Including also should be his right to participate in building his society, his right to inherit from his predecessors as well as his duty to leave behind to his successors his respective share of the fruits of civilization, thus ensuring equal shares for successive generations.

Cabinet of Ministers, Egypt and 21st Century, March 15, 1997.

Following the successful implementation of ERSA, the GOE plans to:

- Continue transforming the Egyptian economy to a market oriented and private-led economy;

- Construct large national projects (Toushki, El-Salaam Canal... etc.) to release congestion in the Old Valley and Delta;

- Develop partnership with private sector and non-government organizations;

- Review components of legislative set-up; and

- Upgrade slums and squatter settlements (EE 1,335.5 million have been spent during 1993-96 to provide utilities and infrastructure to informal settlements).

Despite on-going efforts to improve the living conditions in the South, more efforts are still needed to develop human resources in the study area. Extra international and national development efforts to provide both physical and social infrastructure are also needed.

GOE has formulated plans for the development of southern Governorates on a sectoral level. There is a need for developing strategic and detailed plans for existing and new human settlements to accompany the implementation of these sectoral plans to achieve the national objective. The problem that faces the implementation of these national plans is to find the means to attract investments and human resources to these areas.

\section{IV-3) Institutional Framework:}

Public administrations in the study area face certain limitations. Today, there is no clear delineation of responsibility that is matched with authority in controlling the development in the study area. Development activities in the study area are subject 
to controls administered by several governmental bodies. Legislation governing the development process include Law No. 143/1981 concerning desert land, Law No. 53/1966 (Article 10) for building on agricultural land, Law No. 43/1979 for Local Administration (amended by Law No. 145/1988), and Law No. 3/1982 for physical planning. Ministries of Defense; Agriculture and Land Reclamation; Public Works and Water Resources; Housing, Utilities and Urban Communities; and Tourism are the central agencies that share responsibilities for developing or protecting environmental resources (land and water) in the study area. Responsibilities of those central agencies either overlap, conflict or in case of specific assignment of responsibility lack clear policies and procedures to guide development.

The Governorates of Assuit, Suhag, Qena, Aswan and New Valley manage development in all human settlements, i.e., cities and villages. Law No. 43/1979 for Local Adninistration amended by Law No. 145/1988, organizes such responsibility in a clear set-up. More recently, the Investment Law No. 8/1997 envisions the delegation of land allocation and other investment promotion functions to Governorates. The Departments for Planning and Monitoring, and Offices for Investment Affairs are assigned such responsibilities.

\section{IV-4) Problems Addressed:}

The project addresses the following three problems:

1. The need to initiate and direct the development of human settlements in the study area outside the Nile Valley and Delta: The GOE is committed to directing investments and population outside the inhabited area (4 percent of the gross area). Within the framework of the national agenda to get out of the Nile Valley and Delta, development of the study area needs to be linked with the New Valley Canal (Toushki Canal) development. Government agencies have developed strategies, programs and projects up to the year 2017 that are holistic in their nature with few details. These efforts are coordinated from a sectoral scope and are defined spatially at both national and regional levels, but not at the sub-regional and local levels. There is a need to determine the coordinates of the 18 settlements proposed in the NDLUP that GOPP developed in 1995. This project aims to formulate a strategic plan for the development of human settlements in the South;

2. Diversity and heterogeneity of the study area requires different modalities for development: It consists of three distinct zones with resources providing an opportunity for the diversification of the economic base of the study area. The oasis has its potentials and problems that are different from those of human settlements on the fringe of the Nile Valley. The Governorate of the New Valley, from an environmental point of view, is a fragile area. The Governorates of Assuit, Suhag, Qena and Aswan, on the other hand, face serious economic problems manifested in high rates of unemployment and wide spread poverty. They also face environmental challenges due, in part, to inadequate physical and social infrastructures in existing human settlements. To achieve the national objective, i.e., to attract investments and human resources to the South, the carrying capacity of existing and new human settlements needs to be addressed; and 
3. The need to build the capacity of the development partners in the study area to implement the proposed strategic plan: Existing local institutions (both governmental, and non-governmental entities) responsible for the development in the study area do not have access to environmental information and require systematic monitoring mechanisms to register the impact of new developments. Their capacities to monitor implementation of the proposed strategic plan need to be built. In addition, the newly assigned functions of land allocation and investment promotion will require a new range of technical skills and management capabilities in the study area.

\section{IV-5) End of the Project Situation:}

The expected outputs of this project are:

1. A strategic plan on a sub-regional level for the development of 18 human settlements. including guidelines for development management, strategic projects packaged for the consideration of government bodies, donor agencies and investor groups to finance;

2. Three different development modalities for three types of human settlements that are based on the participation of interested parties and development partners. The first modus operandi is for an extension of an existing city in the old Valley. The second modus operandi is for the development of a traditional community, such as Pharaphrah oasis. The third modus operandi is based on the participation of the business community (investor, bankers and so forth) to initiate development in a virgin area of the Western Desert, Toushki; and

3. Building the capacities of local institutions (both governmental and nongovernmental bodies) on development management. The capacities of the locals will be built to monitor, participate and implement the formulated strategic plan.

The gains from the success of the project are of several folds: First, replicating the project to develop other human settlements in the nation. Second, fostering new modes of production and decision-making that are based on the freedom of choice means adopting a governance system that depends on individual initiatives, participation, and partnership. Third, enabling the development of other human settlements in the study area by the year 2017 using the built capacities and the gained experience.

The target beneficiaries of this project are (1) the staff of General Organization for Physical Planning (GOPP) and officials of the local administration; (2) local population, particularly youth and women; and (3) private sector investors. The indirect target beneficiaries are the general population of the Governorates of the South and all Egyptians.

\section{IV-6) Project Strategy and Implementation Arrangements:}

GOPP is the planning agency responsible for transforming the strategies into articulated physical plans. It is the implementing agency for this nationally executed project. It has the authority either to produce plans for human settlements, amend or approve them. It has special departments for regional studies and research, infrastructure, and plans and programs preparation. It has prepared the National 
Development Land Use Plan (NDLUP) for Egypt, 2017; regional strategies (Sinai, and Upper Egypt); as well as master plans for the development of most settlements ( 8 new settlements and for over 50 and 25 existing cities and villages, respectively) in Egypt. It is implementing the project within the context of the National Land Use Plan developed for Egypt in 1996.

GOPP cooperates with specialized agencies, such as the Egyptian Geological Survey and Industrial Mining Authority (EGSIMA) and National Authority for Remote Sensing and Space Sciences (NARSSS). It works with sectoral ministries to prepare their plans, and define spatial and locational dimensions. The archive of the GOPP has all the studies and information that various governmental agencies have generated. GOPP has gathered, compiled and analyzed this information in the course of preparing the above mentioned strategies and plans. The Database and Documentation Center, which is equipped with the state-of-the art technologies, has the capacity to generate analyze and present data. In addition to its internal resources, GOPP employs experts from different governmental agencies, such as research institutes, who have accesses to information and are able to up-date current accounts.

The Ministry of Housing, Utilities and Urban Communities, the executing agency, formed a Joint Development Committee (JDC) of development partners (both government and non-government entities) to provide the necessary political support and strategy direction. JDC is responsible for providing orientation and enabling policy directions to the development and environmental conservation programs in the study area. All consultations with interested parties take place at different stages of plan preparation, through the JDC and the local councils.

The steering committee for the project consists of representatives of the GOE, and UNDP. They meet on a regular basis, or upon the request of any of the members. Its role is to oversee and monitor the implementation of project activities, verify delivery of inputs and ultimately the successful achievement of project outputs.

This project began by reviewing all studies prepared for the study area that were available in the past to be updated. The output of this effort is a profile that defines strategic issues that a strategic plan addresses. The plan identifies the location of the 18 new settlements (seven in the Western desert and eleven on the fringes of the Nile Valley). The strategic plan identifies strengths and weaknesses in specific zones of the study area, while detecting opportunities for and threats to the development of the study area. In the mean time, interested parties and development partners are identified and invited to participate in project activities.

Working groups (WGs) forum is the main mechanism for formulating and performing the function of coordinated planning and development management. Development partners participate in the process of decision-making in the three communities. They discuss Where to develop? Who is responsible for this development? and How the development will be executed? The working groups the platform upon which all development partners can communicate, exchange information, interact and jointly engage in the process of formulating strategies, plans, project initiatives and coordinated implementation arrangements of programs, projects and actions. 
WGs are established at three different levels. The first level is strategic/sectoral. The second level is issue-specific WGs, which is concerned with specific problems, issues, tasks and so forth. The third level is project design WGs that are concerned with formulating and developing specific projects. Due to the overlap of the three levels and sectors of WGs, an individual may participate in more than one WG. One WG may perform in some cases, the functions of the three levels at once.

Each WG has a coordinator who will act as the WG technical secretariat to organize, conduct and report on the respective working groups' functions. WGs have a predesigned meeting schedule that corresponds to the expected outputs of WGs activities. These outputs, which are produced on timely basis in accordance with life time of the project, are: (a) General cross-sectoral development strategy of the human settlement; Sectoral development strategies; (b) Issue-specific strategies and action programs; (c) Proposed programs and projects identification, listing, description, and appraisal (if possible) for bankable investment large scale projects and design for fast track, small scale projects; and (d) Project screening, sclection and prioritization.

The process has the potential to mobilize local resources, resolve conflicts and implement progress with immediate impact. Many actions could be accomplished with a limited level of effort if it is oriented toward targeting and communicating with relevant parties and providing the proper arrangements for implementation.

WGs functioning is a process that should continue when the project phases out. They will continue the natural cycles of issue identification, investigation, and eventually programs and projects generation.

The project is implemented in three zones of the study area. First, Al Assuiti Valley, about $20 \mathrm{kms}$ East Assuit City, where there is a need to accelerate its development to conserve the valuable agricultural land in the Governorate of Assuit. The adopted modus operandi for development is based on the public-private partnership in development. All development partners and interested parties will participate in working groups, then discuss means to accelerate the growth of the new city. The project will be a catalyst for these discussions. It attempts to build a coalition of the development partners. The working groups, as a mechanism for addressing the problems of the community, will hopefully be institutionalized.

The second area is for a traditional community, that is Pharaphrah oasis. The community is responsible for the development management. International and national professionals that the project provides are facilitators working with the natives to analyze problems and find solutions within their own reach. Poor people can raise capital, but also need assistance on how to access development assistance programs that are available.

The third area is a virgin area, Toushki, where sporadic agricultural development is taking place. The development of a new human settlement in this area is needed to provide specialized service to small agricultural communities in that area. Private firms that will be responsible for the development of the area will stimulate demand by modernizing traditional agriculture. Once agriculture is transformed, production services will become to a large extent supported through fees that clients will be able to pay. Developers will construct social and physical infrastructures on BOOT 
arrangement. Agri-businesses could flourish in this settlement, which could be transformed into an exporting outlet, and host other economic activities, such as mining and tourism.

\section{IV-7) Development and Immediate Objectives:}

The objective of this project is to broaden the scope of development by attracting investments and human resources outside the Nile Valley and Delta to the South while conserving the environment in the study area. Achieving this objective will be through:

1. Articulating a strategic plan for the development for the study area;

2. Establishing a modus operandi for developing three human settlements on the fringe of the Nile Valley, in an oasis and in a virgin land; and

3. Building the capacities of interested parties responsible for implementing the proposed strategic plan and performing investment promotion functions, through creating databases, such as GIS, and by providing specialized training. The proposed strategic plan will include detailed physical, economic and human development strategies. Packages of strategic public and private bankable projects will be prepared for consideration by the Government, donors and private investors to finance.

\section{V) DISCUSSION}

A set of three "strategic operational components" has been identified to provide a clear and well-defined framework for formulation of project activities, outputs and inputs. These strategic components are reflected both in the overall project development objective and in the implementation approach. The strategic components are: strategic planning, capacity building and resource mobilization.

Strategic Planning: The concept is mainly "process oriented" designed to develop and institutionalize sustainable mechanisms for coordinated environmentally-sensible development planning and management. It begins with an initial agreement between interested parties and development partners to formulate a strategic plan to develop human settlements in the South of Egypt. This step is necessary for successfully formulating and implementing the plan. Next is to identify the mandates of the region and its human settlements (existing and new settlements). Then, is to define the mission and values of the region, i.e., to draw the attention to the region's mission in relation to stakeholders' interest. Next two parallel steps. First is to identify external opportunities and threats that the region faces, and second is to identify the region's internal strength and weaknesses. The external environment of the region is defined by acknowledging the forces shaping the future of the region, and clients and competitors of it. Reviewing resources, present strategy and performance assess the internal environment of the region. Having defined the mandates, mission and values, and extemal and internal environments, the working groups are ready to list strategic issues as means to identify fundamental policy questions affecting the mandates, mission and values, product, clients, cost, financing and management of the region. Next, WGs are ready to propose strategies (both long-term and short-term) accompanied by a list of action plans including programs and projects to be prioritized. All interested parties discuss these strategies in a Strategy Consultation. Next, WGs agree on a criterion to prioritize the list of programs and projects proposed during the consultation. 
Prioritized projects are then analyzed and packaged as strategic investment packages for government, donors and private investors to finance.

Capacity Building: It is a component that cuts across all activities and relates to all levels of decision-making and implementation. The basic feature of this component is that it targets development partners that may need a certain leverage to enable them to assume their respective roles at the level needed for successful "partnership". The project has identified the specific areas of capacity building to include urban settlements management, local leadership, income generation for youth and women, information generation and use, and investment promotion.

Resource Mobilization: It is an integral strategic component of the project activities. Due to the specific nature of the project, (UNDP involvement) special considerations have been given to the potential role of international support and donor agencies. UNDP is capable of providing an umbrella forum to attract national and international development agencies. This is reflected in assigning "organization and coordination with donor agencies" as a specific activity and calling for intermittent meetings and workshops with national and international funding agencies. The flexibility of the project management and the ability of the project to articulate the interests and project needs of the communities in the study area is the most important condition for successful resource mobilization. Particular emphasis will also be given to the involvement of funding agencies at the early stages of strategy and investment project formulation.

Promoting private investment is an important focus of the resource mobilization component. Promotion of private investment will be targeted both at the levels of small businesses and large investment packages. The project will be engaged into increasing the access of micro and small businesses to capital and credit through ${ }^{\prime}$ effective inter-mediation with banks, and small and micro enterprise (SMEs) development assistance programs. Simultaneously, the project is expected to identify opportunities for private investments in areas such as land development, tourism, infrastructure or industrial ventures. The intention is to bring together the components of an investment package (such as land, license and concessions) that may attract investors, and not to produce feasibility studies of projects then attempt to market them. The project will hold a major investment conference to market these opportunities.

\section{VI) CONCLUDING REMARKS}

The project represents a departure in the development plaming practice in Egypt. First, it is designed to associate thinking at the conceptual, abstracted level with the implementation and execution in reality. The set-up of participatory structures (JDC and working groups) aims to articulate plan that is feasible, executable and has the political support at the national and local levels. Furthermore, it links the micro and macro policies--The success of the efforts of the Government at the macro level can be insured only through interaction with and listening to people.

Second, in formulating the strategic plan for human settlements in the South of Egypt, GOPP is considering the interests of stakeholders. The channels for information flow from the local areas to the GOPP, the generation, dissemination and exchange of information in the JDC and working groups' meetings enables 
GOPP to cross-examine the information checking its validity and reliability. Also, once interested parties get on board in the working groups and participate in the decision-making, they assume responsibility and ownership of the produced project. These channels of information will enforce the issue of transparency between central, local and civil society organizations.

Third, observing the extemal threats and internal weaknesses in deciding on specific actions is an appropriate way to plan in a continuously transforming context due, in part, to globalization. This means that GOPP and local administrators have adopted the motto "Think globally, act locally," which means a radical institutional transformation in the way development plans are prepared in Egypt. Also, fostering a participatory decision-making process is another brick in the wall of institutional transformation, which means understanding the political dimension of the planning profession.

Fourth, the project is considering the real competitors and regards actual collaborators. This is evident from the attempt to diversify the economic base of the new settlements, and linking them with the existing ones.

\section{VII) REFRENCES}

Abu-Zekry, Tarek and Ahmed El-Kholei, (1993) "The Response of Urban Planning to Global Transformations: Redefining the Planning Profession," presented at Urban Planning and Its Role in Development, sponsored by the Arab League and the General Organization for Physical Planning, Cairo: Egypt, (text in Arabic).

Altshuler, Allen, ([1965] 1973) "The Goals of Comprehensive Planning," in A Reader in Planning Theory, A. Faludi (editor), New York: Pergamon Press.

Amin, Samir (1989), Eurocentrism, New York, NY: Monthly Review Press. (1985) Delinking: Towards a Polycentric World, London, UK: Zed Books, Ltd.

Amirahmadi, Hooshang (1991), "Third World Economic Imbalances and Global Restructuring: Prospects for Medium-Term Growth," a paper presented at the Consortium on Development Studies meeting, Seoul National University, Seoul, Korea.

Beauregard, Robert A. (1991) "Without a Net: Modernist Planning and the Postmodern Abyss," Journal of Planning Education and Research, 10 (3): 189-94.

Cabinet of Ministers (1997) Egypt and 21st Century, Cairo, Egypt.

Christensen, K (1985) "Coping with Uncertainty in Planning," Journal of American Planning Association, 51 (1): 63.

El-Kholei, Ahmed and Tarek Abu-Zekry (1993) "The Impact of Global Transformations on the Process of Urbanization in Newly Industrialized 
Countries: Lessons for Future Egyptian Urban Policies, "Al-Azhar Third International Engineering Conference, Volume 2, City and Regional Planning, 18:21, Cairo, Egypt.

Friedman, Milton (1982) Capitalism and Freedom, Chicago, IL: The University of Chicago Press.

Kuhn, Thomas (1960) The Structure of Scientific Revolutions, Chicago, IL.: The University of Chicago Press.

Lindblom, Charles, ([1959] 1973) The Science of Muddling Through," in A Reader in Planning Theory, A. Faludi (editor), New York: Pergamon Press.

Institute for National Planning, Egypt Human development Report, 1996, Nasr City, Cairo, Egypt.

Mandelbaum, Seymour j. (1991) "Telling Stories," Journal of Planing Education and Research, 10 (3): 209-214.

Milroy, Beth Moore (1991) "Into Postmodern Weightlessness," Joumal of Planning Education and Research, 10(3): 181-187.

Schon, Donald A. (1983) The Reflective Practitioner: How Professionals Think in Action, USA: Basic Books.

(1982) "Some of What a Planner Knows: A Case Study" of Knowing-in-Practice, "Journal of American Planning Association, 49 (3): 351-364.

Soja, Edward and Richard J. Tobin ([1975] 1979) "The Geography of Modernization: Paths, Patterns and Processes of Spatial Change in Developing Countries," in Third World Urbanization, Janet Abu-Lughod and Richard Hays, Jr. (editors), New York, NY: Methuen.

Schumacher, E.F. (1973) Small is Beautiful: Economics as if People Mattered, New York, NY: Harper \& Row, Publishers.

Slater, D. ([1974] 1979) "Colonialism and the Spatial Structure of Under Development; Outlines of an Alternative Approach, with special reference to. Tanzania," in Third World Urbanization, Janet Abu-Lughod and Richard Hays, Jr. (editors), New York, NY: Methuen.

Wallerstein, Immanuel (1989) Historical Capitalism, New York, NY: Verso.

World Bank, 1996 Global Economic Prospects and the Developing Countries, Washington, DC.

Webber, Melvin (1983) "The Myth of Rationality: Development Planning Reconsidered, "Environment and Planning B: Planning and Design, 10 (1): 89-100. 


\section{VIII) NOMENCLATURE}

$\begin{array}{ll}\text { BOOT } & \text { Build, Own, Operate and Transfer } \\ \text { EGSIMA } & \text { Egyptian Geological Survey and Industrial Mining Authority } \\ \text { ERSA } & \text { Economic Restructuring and Structural Adjustment } \\ \text { GIS } & \text { Geographic Information System } \\ \text { GOE } & \text { Government of Egypt } \\ \text { GOPP } & \text { General Organization for Physical Planning } \\ \text { JDC } & \text { Joint Developing Committee } \\ \text { MHUUC } & \text { Ministry of Housing, Utilities and Urban Communities } \\ \text { MNCs } & \text { Multi-National Corporations } \\ \text { NARSSS } & \text { National Authority for Remote Sensing and Space Sciences } \\ \text { NDLUP } & \text { National Development Land Use Plan } \\ \text { NGOs } & \text { Non-Government Organizations } \\ \text { NICs } & \text { Newly Industrialized Countries } \\ \text { PMU } & \text { Project Management Unit } \\ \text { SMEs } & \text { Small and Micro Enterprises } \\ \text { UNDP } & \text { United Nations Development Programme } \\ \text { WGs } & \text { Working Groups }\end{array}$


التحول في النموذزج الإرشادي لفرأسات التنمية الإقليمية والحضرية في عصر المتولمة: حالة تنمية جنوب مصدر

د.م. ا-حمل عثمان الخولى

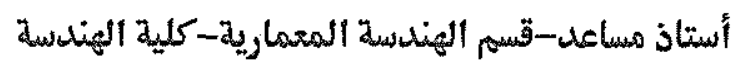

جامعة المنوفية-جممهورية مصر المبربية

استحوذت إدارة تنمية المستوطنات البشرية في دول الدالم النامي اهتمام المخططين، فتد صاحب التثاوت الإقليميي مشكلات حضرية منها الثلانهور البيني، وأزمات الإسكان، والبطالة ...الخ، وقل طبقت الحكومات والجهات المانحة مناهج تنموية كان نصيبها من

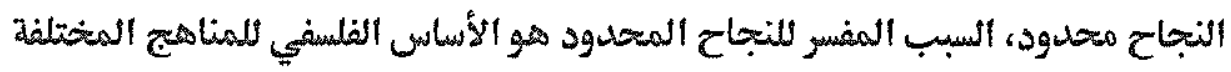

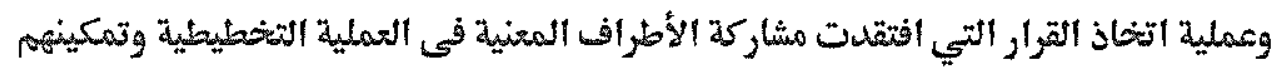
في مراحل التنقيا.

ويصاحب بزوغ عصمر المولمة أسلوب جليد في تكوين رأس المال مصحموب بصيغ جلديلسة

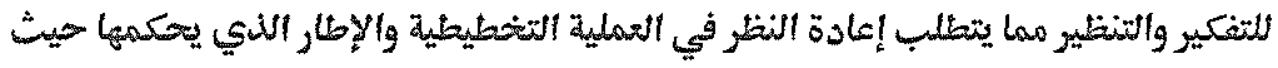

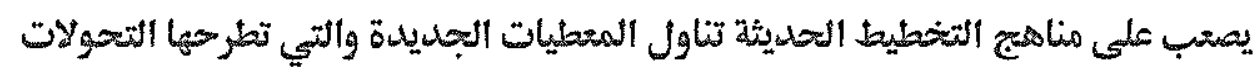
الاقتصادية والاجتماعية والديياسية المعاصرة. ويستحوض البحث الستخحام منهاج ما بعل ألحداثة في تصميم مشروع المثخطط الاستراتيجي لتنهية المثدتوطنات البشرية في جنوب معمر والمبنى على ترسيخ أشكال للمشاركة والتمكين

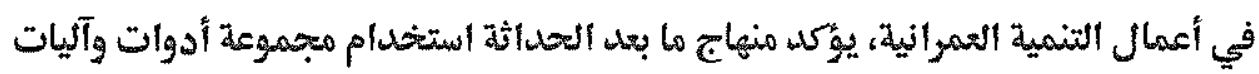
تحليلية وتفسيرية بئسف التنوير حيث تثحرل الدملية التخطيطية من عملية اقترأح حلول

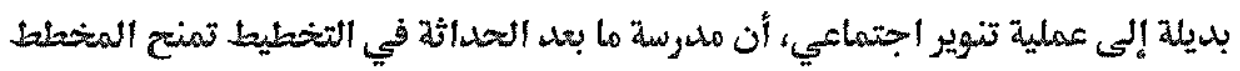
إطار مناسب لفيهم والتحامل مع التحولات الاجتماعية الحالية والتي تتسمم باليسرعة والديناميكية كما تمنحه تحريفات جدياة لمشكلات قديمة وبالتالي يمكن الوصول إلبي حلول مناسبة للقرن . 